\title{
Detecting and Analyzing Hydrolytic Enzymes of Industrial Significance in two Streptomyces Strains Isolated from the Soil
}

\author{
Olaitan Akintunde
}

\section{ABSTRACT}

Two Streptomyces strains were isolated from a soil sample in Louisiana. They were identified via $16 \mathrm{~S}$ rRNA sequencing and phylogeny. To detect the presence of hydrolytic enzymes, starch, carboxymethyl-cellulose (CMC), lipase reagent, and Milk (casein) were used as substrates to detect the production of amylase, cellulase, lipase and casease respectively. Both strains showed the ability to hydrolyze starch, and cellulose, while only strain SWHR10 displayed lipase activity. In addition, strain SWHR10 showed better amylase and cellulase activity. Hemolysis, gelatinase and catalase tests were also conducted. This study further validates that Streptomyces remain a powerhouse of hydrolytic enzymes with industrial and economic importance.

Keywords: Hydrolytic enzymes, cellulase, biotechnology, Lipase, Streptomyces.

\section{INTRODUCTION}

Streptomyces produce diverse secondary metabolites, the bulk of which are antibiotics [4]. They are also known to produce a host of extracellular enzymes that enables them to break down complex compounds such as chitin or cellulose, which aid their survival in the complex environment they inhabit by allowing for nutrient availability while interacting with other organisms [7]. Enzymes, such as protease, chitinase, lipase, catalase and cellulase are essential for nutrient mineralization, breaking down organic matter and plant growth support. They can also be deployed as a defense strategy against the chitin, lipid and protein of pests [4]. The genome of Streptomyces is believed to encode a host of secreted proteins including cellulase, chitinase, etc. [7].

Streptomyces are able to produce vitamins and enzymes such as amylases that could be employed for bioconversion and other commercial purposes, during the vegetative growth phase [1]. At a later growth phase, they can produce secondary metabolites such as pigments, antibiotics and other notable metabolites including antifungal, antiparasites, etc. [1]. Screening samples from the soil or marine environment for Streptomyces and other actinomycetes while assaying for bioactivity may lead to the identification of novel enzymes of industrial significance [7], [19], [17].

The goal of this study is to evaluate the presence of hydrolytic enzymes of biotechnological interest in Streptomyces strains isolated from the soil. Hydrolytic enzymes such as amylase and cellulase have numerous industrial application such as production of paper, textile, fermentable sugars/monosaccharides or in biodegradation of
Published Online: June 21, 2021

ISSN: $2684-5199$

DOI: $10.24018 /$ ejbio.2021.2.3.214

\section{Olaitan Akintunde*}

Department of Biology, University of Louisiana at Lafayette, Lafayette, LA USA.

(e-mail: oly2akin@gmail.com)

*Corresponding Author waste products while lipases can be added to detergents as they help to break down oil stains [19].

\section{MATERIALS AND METHODS}

\section{A. Strain Isolation}

Serially diluted soil samples from Lafayette, Louisiana were plated on glycerol yeast extract agar $(5 \mathrm{~g} / \mathrm{L}$ glycerol; $2 \mathrm{~g} / \mathrm{L}$ yeast extract, $1 \mathrm{~g} / \mathrm{L} \mathrm{K}_{2} \mathrm{HPO}_{4}, 15 \mathrm{~g} / \mathrm{L}$ agar) and putative actinomycetes or Streptomyces were identified via pigmentation. Two colonies were selected for further studies. Isolates were cultivated and propagated on ISP2-yeast extract malt extract agar (yeast extract $(4 \mathrm{~g} / \mathrm{l})$, malt extract $(10 \mathrm{~g} / \mathrm{L})$, dextrose $(4 \mathrm{~g} / \mathrm{L})$ and agar $(15 \mathrm{~g} / \mathrm{L})$. Aerial and vegetative hyphae were observed [23].

\section{B. 16S rRNA Analysis}

The 16S rRNA gene for both organisms were amplified via colony PCR with the forward primer; $63 \mathrm{f}-5$ '-CAG GCC TAA CAC ATG CAA GTC-3' and reverse primer; 1387r-5'GGG CGG WGT GTA CAA GGC-3' primers [20]. Amplification started with an initial denaturation step for 3 min. at $95^{\circ} \mathrm{C}$, followed by 25 cycles consisting of 30 seconds at $95{ }^{\circ} \mathrm{C}, 30$ seconds at $48{ }^{\circ} \mathrm{C}$ (annealing) and 45 seconds at $72{ }^{\circ} \mathrm{C}$ (extension) and concluded with a final extension step for 5 minutes at $72{ }^{\circ} \mathrm{C}$. Purified PCR products were sent to functional biosciences (WI, USA) for sanger sequencing. The sequences were analyzed and aligned via the Basic Local Alignment Search Tool (BLAST). Phylogenetic trees were constructed using the MEGA software (version 7) [9]. 


\section{Media Composition for Hydrolysis Test}

M9 media (3 g/L KH $\mathrm{KHO}_{4}, 6 \mathrm{~g} / \mathrm{L} \mathrm{Na}_{2} \mathrm{HPO}_{4}, 0.5 \mathrm{~g} / \mathrm{L} \mathrm{NaCl}$, $1 \mathrm{~g} / \mathrm{L} \mathrm{NH} 4 \mathrm{Cl}$ ), $1 \mathrm{mM} \mathrm{MgSO} 4,15 \mathrm{~g} / \mathrm{L}$ agar, and $1 \mathrm{ml} / \mathrm{L}$ trace element solution $\left(50 \mathrm{~g} / \mathrm{L} \mathrm{Na}_{2}\right.$-EDTA, $22 \mathrm{~g} / \mathrm{L} \mathrm{ZnSO}_{4} \times 7 \mathrm{H}_{2} \mathrm{O}$, $5.54 \mathrm{~g} / \mathrm{L} \mathrm{CaCl}{ }_{2} \times 2 \mathrm{H}_{2} \mathrm{O}, 5.06 \mathrm{~g} / \mathrm{L} \mathrm{MnCl}_{2} \times 4 \mathrm{H}_{2} \mathrm{O}, 5 \mathrm{~g} / \mathrm{L} \mathrm{FeSO}_{4}$ $\times 4 \mathrm{H}_{2} \mathrm{O}, 1.10 \mathrm{~g} / \mathrm{L} \mathrm{NH} \mathrm{Mo}_{7} \mathrm{O}_{24} \times 4 \mathrm{H}_{2} \mathrm{O}, 1.57 \mathrm{~g} / \mathrm{L} \mathrm{CuSO} \mathrm{Cu}_{4} \times$ $5 \mathrm{H}_{2} \mathrm{O}, 1.61 \mathrm{~g} / \mathrm{L} \mathrm{CoCl}_{2} \times 6 \mathrm{H}_{2} \mathrm{O}$; [18]) was prepared. The media was supplemented with $10 \mathrm{~g} / \mathrm{L}$ Carboxy-methyl cellulose (CMC) for cellulase detection or $30 \mathrm{ml} / \mathrm{L}$ difco lipase reagent (tributyrin \& polysorbate 80 ) for lipase detection. For casease detection, tryptic soy agar (TSA)(15 g/L tryptone, $5 \mathrm{~g} / \mathrm{L}$ soytone, $5 \mathrm{~g} / \mathrm{L}$ sodium chloride, $15 \mathrm{~g} / \mathrm{L}$ agar) with $10 \%$ skimmed milk was prepared. For amylase detection, difco starch agar (3 g/L beef extract, $10 \mathrm{~g} / \mathrm{L}$ soluble starch and $15 \mathrm{~g} / \mathrm{L}$ agar) was used. TSA with 5\% sheep's blood was used to screen for hemolysis. Tryptic soy broth (TSB) supplemented with $12 \%$ gelatin was used for gelatin hydrolysis/liquefaction test.

\section{Hydrolysis Detection}

For cellulase activity, M9 media with CMC was inoculated with test organisms and incubated for 4 days at $30^{\circ} \mathrm{C}$, followed by staining with $1 \%$ congo red for $15 \mathrm{~min}$ and destaining with $1 \mathrm{M} \mathrm{NaCl}$ [14]. Plates were observed for the presence a yellow clearance zone. For amylase activity, iodine was added to $72 \mathrm{~h}$. old starch agar cultures to detect clearance zone from starch hydrolysis while for Lipase activity, test organisms were inoculated on M9 agar with lipase reagent, incubated for 3-5 days, and zone of clearance was observed. For casease activity, skimmed milk agar inoculated with test organisms were observed for clearance zone after 72 hours of incubation. For gelatin hydrolysis, the media was inoculated and incubated for 72 hours after which it was cooled down in the refrigerator before observing for liquefaction.

\section{E. Enzyme Activity}

Cellulase, amylase, lipase and casease activity was measured via hydrolytic capacity which is defined as the ratio of clearance zone diameter to colony diameter [11], [17], [21]. The larger ratio was treated as equivalent to higher enzyme activity.

\section{F. Statistical Analysis}

All hydrolysis tests were done in triplicates. Mean hydrolysis capacity and standard deviation were calculated and reported as mean \pm standard deviation. A student t-test was performed to determine statistical significance.

\section{RESUlTS AND DISCUSSION}

Two strains named Streptomyces sp. strain SWHR10 and Streptomyces sp. strain SWHR20 were isolated from the soil. BLAST analysis reveals that strain SWHR10 has a $99.21 \%$ similarity with Streptomyces alboniger while strain SWHR20 has a $99.62 \%$ similarity with Streptomyces puniceus. Phylogenetic analysis shows that strain SWHR10 is closely related S. alboniger strains (Fig. 1 a) while strain SWHR20 paired up with $S$. puniceus. SWHR20 also shares the same clade with $S$. phaeofaciens (Fig. $1 \mathrm{~b}$ ).
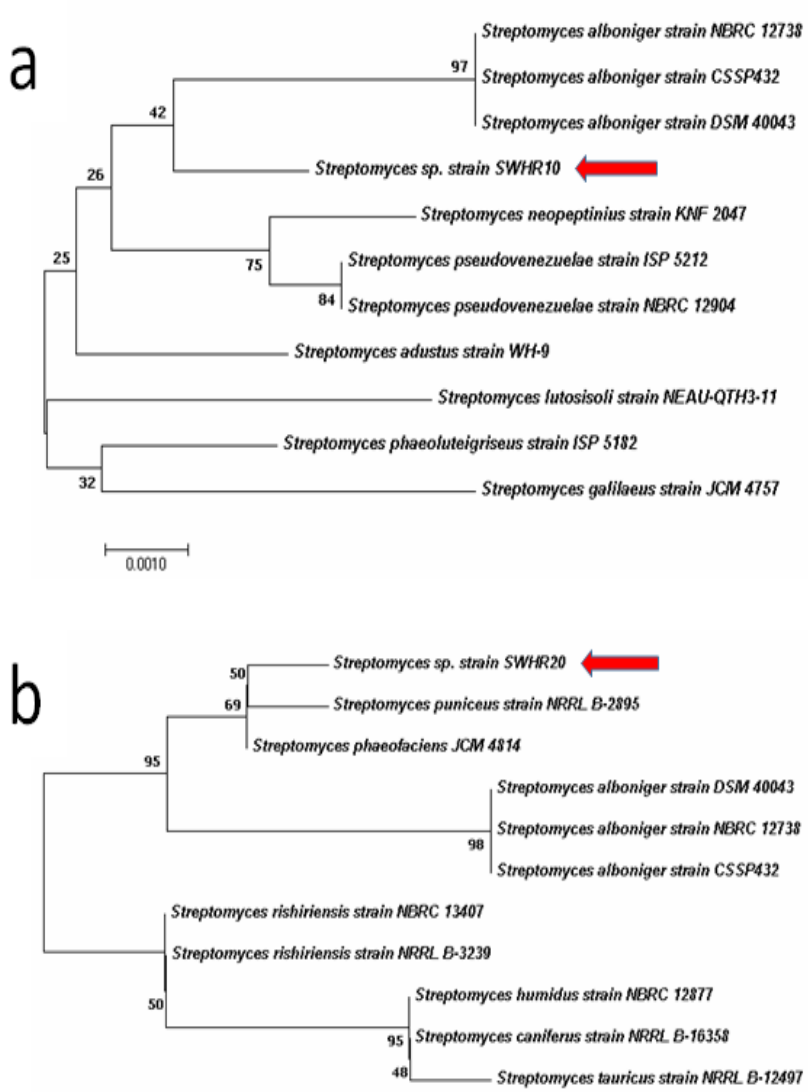

Fig. 1. Phylogenetic analysis of Strains SWHR10 (a) and SWHR20 (b). Neighbor joining tree was generated with 16S rRNA sequence alignment. Scale bar represents number of substitutions per site. Bootstrap values based on 100 replicates are shown at the nodes. Red arrows indicate the position of the respective strains.

For amylase, strain SWHR10 showed a higher hydrolytic capacity of 2.3 compared to SWHR20 suggesting more enzyme activity or more efficiency at breaking down starch (Fig. 2 a, Table I). Amylase can be used in the food industry for baking, production high corn fructose syrup as well as paper/pulp [15].

Similarly, strain SWHR10 displayed a better cellulase activity with a hydrolytic capacity of 2.36 (Fig. 2 b, Table I). A hydrolytic capacity as high as 5.6 has been reported for cellulase producing Streptomyces strain $\mathrm{S}_{-} \mathrm{G}_{20}$ [10]. Cellulose is present in abundance in wood. Cellulase would allow the cheap conversion of lignocellulose biomass into simple sugars such as glucose, a product with diverse applicability, such as food or ethanol production. Glucose recovered from cellulose hydrolysis can also be feed to oleaginous organisms to produce fatty acids and triglycerides that can be harnessed for biodiesel biosynthesis [16], [22]. This makes cellulase of huge importance for green and renewable energy. Cellulases are also used for bio polishing in the textile industry [11], [19]. Only strain SWHR10 was able to utilize and break down lipids substrates while strain SWHR20 did not grow on the media (Fig. 2 c, Table I). Lipase enables the hydrolysis of fat and oil, and thus useful for cosmetics and detergent production [6]. 


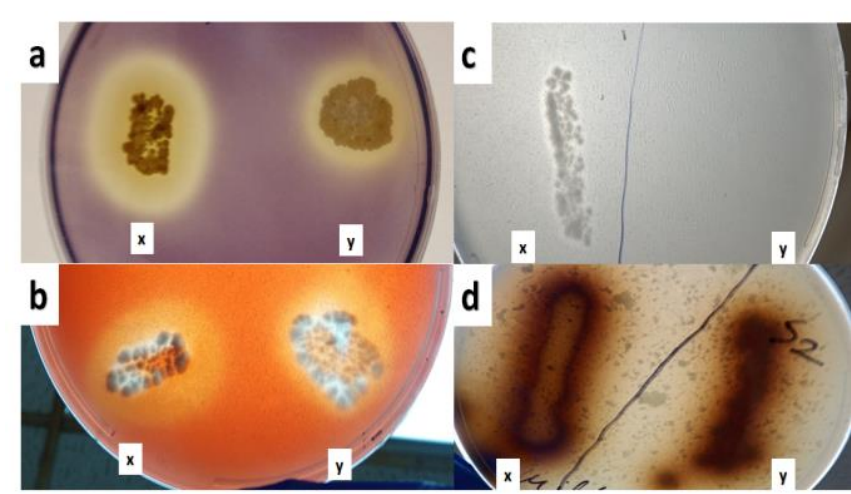

Fig. 2. Detection of hydrolytic enzymes on different substrates. a- Starch agar plate, b- CMC Plate, c- Lipase Reagent Plate d-Milk agar plate. Xstrain SWHR10, y- strain SWHR20.

Cellulases from Streptomyces with thermal and $\mathrm{pH}$ stability have been reported and successfully used as detergent additive [3]. Similarly, acidophilic, and thermophilic amylases that can be applied in alcohol fermentation and baking have been described in Streptomyces erumpens [3]. Cellulase, amylase and protease have been detected in Streptomyces sp Strain A which was isolated from the soil [8].

TABLE 1. ENZYME ACTIVITY OF STRAINS SWHR10 AND SWHR20. NDNO DETECTED ACTIVITY

\begin{tabular}{ccccc}
\hline \hline \multirow{2}{*}{ Strains } & \multicolumn{4}{c}{$\begin{array}{c}\text { Enzyme activity via hydrolytic capacity (clearance zone } \\
\text { diameter(mm)/colony diameter(mm)) } \pm \text { SD }\end{array}$} \\
\cline { 2 - 5 } & Amylase & Cellulase & Lipase & Casease \\
\hline $\begin{array}{c}\text { Strain } \\
\text { SWHR10 } \\
\text { Strain } \\
\text { SWHR20 }\end{array}$ & $2.30 \pm 0.17^{\mathrm{a}}$ & $2.36 \pm 0.12^{\mathrm{a}}$ & $1.03 \pm 0.23$ & ND \\
& $1.14 \pm 0.11^{\mathrm{b}}$ & $1.72 \pm 0.24^{\mathrm{b}}$ & ND & ND \\
\hline
\end{tabular}

Letters $\mathrm{a}$ and $\mathrm{b}$ within the same column shows statistical significance $(\mathrm{p}<0.05)$.

Casease enzyme is used in the dairy industry for cheese production. Neither strains displayed casease activity or the ability to break down milk protein (Fig. 2 d, Table I). However, strain SWHR20 caused hemolysis on blood agar plate suggesting the presence of proteolytic ability and possible pathogenicity (Fig. 3, Table II).

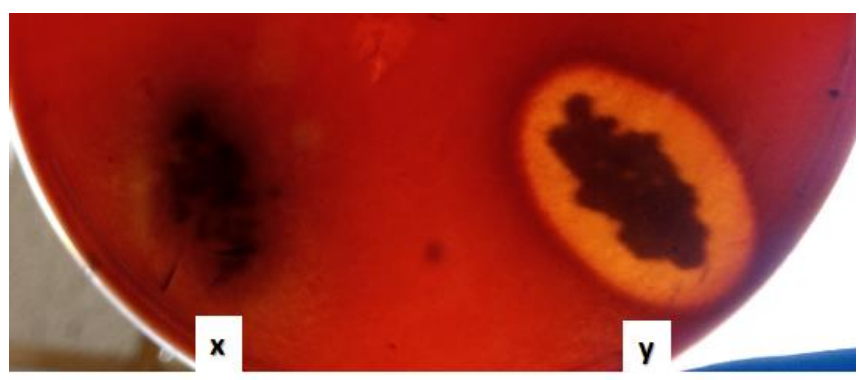

Fig. 3. Hemolysis test of strains SWHR10 (x) and SWHR20 (y).

Hemolytic test has also been suggested as a tool for screening bacteria with the ability to produce biosurfactants [13]. While this is not foolproof as hemolysis can be due to the production of other metabolites, and more precise assays are required, it can be used as a preliminary step for identifying biosurfactant producers when screening a bunch of microbial isolates [13]. Biosurfactants enable the solubility and degradation of hydrophobic organic compounds and are thus applicable in bioremediation or pollutant clean up. Both strains tested negative for gelatin hydrolysis while strain SWHR10 was positive for catalase (Table II).

TABLE II: BIOCHEMICAL TESTS AND CULTURAL CHARACTERISTICS OF STRAINS SWHR10 AND SWHR20

\begin{tabular}{|c|c|c|c|c|c|}
\hline \multirow{2}{*}{ Strains } & \multicolumn{3}{|c|}{ Other biochemical tests } & \multicolumn{2}{|c|}{$\begin{array}{c}\text { Cultural characteristics } \\
\text { (Color) }\end{array}$} \\
\hline & Gelatin & $\begin{array}{l}\text { Hemo } \\
\text { lysis }\end{array}$ & Catalase & $\begin{array}{c}\text { Aerial } \\
\text { hyphae }\end{array}$ & $\begin{array}{c}\text { Vegetative } \\
\text { hyphae }\end{array}$ \\
\hline $\begin{array}{l}\text { Strain } \\
\text { SWHR10 }\end{array}$ & - & - & + & $\begin{array}{l}\text { Whitish } \\
\text { grey }\end{array}$ & Brown \\
\hline $\begin{array}{c}\text { Strain } \\
\text { SWHR20 }\end{array}$ & - & + & - & $\begin{array}{l}\text { Light } \\
\text { brown }\end{array}$ & $\begin{array}{l}\text { Light } \\
\text { brown }\end{array}$ \\
\hline
\end{tabular}

Antibiotics, puromycin and dinactin have been reported from a strain of $S$. alboniger and S. puniceus respectively [2] [5]. However, the production of enzymes such as cellulase, amylase, lipase etc. have not been extensively studied or reported in these Streptomyces species.

\section{CONCLUSION}

There is a continuous quest for novel enzymes from natural environments as enzymes with high productivity, better specificity, stability to $\mathrm{pH}$ and temperature as well as low production cost are preferable for industrial bioprocesses [3]. Strain SWHR10 displayed superior hydrolytic capacity with starch, cellulose and lipids as substrates. Genome hunting can be done via search for enzyme encoding sequence within the genome of an organism [6]. Cloning, overexpression, and activity screening of putative enzymes have been used in the discovery and optimization of new enzymes [6]. The genome of this strain needs to be investigated and the biosynthetic genes for these enzymes should be identified. These genes can be cloned into expression vectors and propagated in a suitable heterologous host for industrial scale up production of respective enzymes. Furthermore, the production of an enzyme is affected by a number of factors such as $\mathrm{pH}$, temperature, nutrient availability etc., [12]. Thus the effect of these factors on enzyme yield needs to be investigated in both isolates. Several yet to be discovered or studied actinomycetes are present in the soil, leaving more room for the bio-exploration of industrial enzymes.

\section{ACKNOWLEDGMENT}

The author would like to thank the department of Biology, UL Lafayette for providing the facility for this research.

\section{REFERENCES}

[1] S. Barbuto Ferraiuolo, M. Cammarota, C. Schiraldi, et al. Streptomycetes as platform for biotechnological production processes of drugs. Appl Microbiol Biotechnol vol. 105, pp. 551-568, 2021.

[2] C., MacDonald, \& R. C. Piper. Puromycin- and methotrexateresistance cassettes and optimized Cre-recombinase expression plasmids for use in yeast. Yeast (Chichester, England), vol. 32(5), pp. 423-438, 2015.

[3] D. Prakash, N Nawani, M Prakash, M. Bodas, A. Mandal, M. Khetmalas, B. Kapadnis . Actinomycetes: a repertory of green catalysts with a potential revenue resource. Biomed Res Int. vol. 2013, pp. $264020,2013$.

[4] F M. Rashad, H M. Fathy, A S. El-Zayat, A M. Elghonaimy, 2015 Isolation and characterization of multifunctional Streptomyces species with antimicrobial, nematicidal and phytohormone activities from 
marine environments in Egypt, Microbiological Research, vol. 175, pp 34-47.

[5] A. Hussain, M. A. Rather, M. S. Dar, N. A Dangroo, M. A. Aga, A. Qayum, A. Shah, A. M. Z. Ahmad, M. J. Dar, \& Q. P. Hassan. Streptomyces puniceus strain AS13., Production, characterization and evaluation of bioactive metabolites: A new face of dinactin as an antitumor antibiotic. Microbiological research, vol. 207, pp. 196-202, 2018.

[6] J. L.Adrio, \& A. L. Demain, (2014). Microbial enzymes: tools for biotechnological processes. Biomolecules, vol. 4(1), pp. 117-139.

[7] K.F. Chater, S. Biró, K.J. Lee, T. Palmer, H. Schrempf. The complex extracellular biology of Streptomyces. FEMS Microbiology Reviews. vol. 34, pp. 171-198, 2010.

[8] D. M. Kavya, S. Magapu, D.M. Nagalakshmi. Isolation And Screening of Streptomyces Sp. From Coringa Mangrove Soils for Enzyme Production and Antimicrobial Activity IJPCBS 2012, vol. 2(1), pp. 110-116, 2012.

[9] S. Kumar, G. Stecher, and K. Tamura. MEGA7: Molecular Evolutionary Genetics Analysis version 7.0 for bigger datasets. Molecular Biology and Evolution vol. 33, pp. 1870-1874, (2016).

[10] M. Samira, R. Mohammad and G. Gholamreza, 2011. Carboxymethylcellulase and Filter-paperase Activity of New Strains Isolated from Persian Gulf. Microbiology Journal, vol. 1, pp. 8-16.

[11] P. Gupta, K. Samant, A. Sahu, "Isolation of Cellulose-Degrading Bacteria and Determination of Their Cellulolytic Potential", International Journal of Microbiology, vol. 2012, pp. 1-5, 2012.

[12] R. Bellaouchi, H. Abouloifa, Y. Rokni, A. Hasnaoui, N. Ghabbour, A. Hakkou, A. Bechchari, A Asehraou. Characterization and optimization of extracellular enzymes production by Aspergillus niger strains isolated from date by-products. J Genet Eng Biotechnol, vol. 19(1), pp. 50, 2021.

[13] R. Thavasi, S. Sharma, S. Jayalakshmi (2011) Evaluation of Screening Methods for the Isolation of Biosurfactant Producing Marine Bacteria. J Pet Environ Biotechnol S1:001. doi:10.4172/2157-7463.S1-001.

[14] RI Santamaría, A Martínez-Carrasco, R Sánchez de la Nieta, LM Torres-Vila, R Bonal, J Martín, R Tormo, F Reyes, Genilloud O, Díaz M. Characterization of Actinomycetes Strains Isolated from the Intestinal Tract and Feces of the Larvae of the Longhorn Beetle Cerambyx welensii. Microorganisms. 2020 Dec 16;8(12):2013. doi 10.3390/microorganisms8122013. PMID: 33339339; PMCID: PMC7766275.

[15] S. Nigam. Microbial enzymes with special characteristics for biotechnological applications. Biomolecules. vol 3(3), pp 597-611. 2013.

[16] S., Ellilä, L., Fonseca, C. Uchima, et al. Development of a low-cost cellulase production process using Trichoderma reesei for Brazilian biorefineries. Biotechnol Biofuels vol. 10, pp. 30, 2017.

[17] TJ Hossain, SI Chowdhury, HA Mozumder, MNA Chowdhury, F Ali, N Rahman and S Dey Hydrolytic Exoenzymes Produced by Bacteria Isolated and Identified from the Gastrointestinal Tract of Bombay Duck. Front. Microbiol. vol. 11, pp. 2097, 2020.

[18] W. Vishniac and M. Santer, The thiobacilli. Molecular Biology Review. Vol. 21, pp. 195-213 (1957)

[19] S. Mukhtar, A. Zaheer, D. Aiysha, K.A. Malik, S. Mehnaz. Actinomycetes: A Source of Industrially Important Enzymes. J Proteomics Bioinform vol. 10, pp. 316-319, (2017).

[20] JR Marchesi, T Sato, AJ Weightman, TA Martin, JC Fry, SJ Hiom, D Dymock, WG Wade. Design and evaluation of useful bacteriumspecific PCR primers that amplify genes coding for bacterial $16 \mathrm{~S}$ rRNA. Appl Environ Microbiol. vol. 64(2), pp. 795-9, 1998.

[21] B.C., Behera, et al. "Isolation and Identification of Cellulose Degrading Bacteria from Mangrove Soil of Mahanadi River Delta and Their Cellulase Production Ability", American Journal of Microbiological Research vol 2.1, pp. 41-46, 2014.

[22] S. Comba, M. Sabatini, S. Menendez-Bravo, A. Arabolaza, H. Gramajo. Engineering a Streptomyces coelicolor biosynthesis pathway into Escherichia coli for high yield triglyceride production. Biotechnol Biofuels. vol. 7(1):172. 2014.

[23] O. G. Akintunde. "Production of an Antibiotic-like Activity by Streptomyces sp. COUK1 under Different Growth Conditions" Electronic Theses and Dissertations, Paper 2412, 2014. 